peutic application and cited four cases in which brewers yeast was used with satisfactory results. Since this time I have used fresh brewers yeast in all cases of tuberculosis, in private practice and in the wards of the German Hospital, and believe, as I did, and as amply verified in the paper of Huggard and Marland that brewers yeast is a valuable remedy in cases of tuberculosis. Brewers yeast has proved itself, if anything, even more gratifying in its results in a number of cases of bronchopneumonia where resolution of the lung and convalescence was too prolonged. By giving it in large doses of from two to three ounces three times a day resolution has been hastened, and the patients have improved in weight and strength.

400 Franklin street.

Julius Ullmay.

\section{Expulsion of Placenta Before Birth of Child.}

Chicago, July 4, 1905.

To the Editor:-Relevant to the inquiry of Dr. Butt in The Journal, July 1 , page 60 , I would say that I was called on June 15 by a midwife to a case in which the third stage of labor had preceded the second, the placenta having been delivered about half an hour before my arrival. The os was the size of a silver dollar, with a right sacro-anterior presentation of the fetus. The woman's pulse was 90 , small. She was pale and weak, but her condition was not alarming. Hemorrhage had ceased. In about forty minutes she expelled, unassisted, an exsanguinated male fetus, apparently at term. The midwife was reticent as to the history of the case and her connection with it, but I gathered from the husband, who could speak little or no English, that there had been hemorrhages for some weeks prior to the woman's confinement. She had had four children, all living, of whom the births had been normal. So far as known she made an uneventful recovery. II. A. HAsKeiL, M.D. Goodrich, N. D., July 6, 1905 .

To the Editor:-As expulsion of placenta before that of child seems rather uncommon, the following may be interesting: The patient was seen Aug. 5, 1904. Miss - - primipara, white, aged 22, had taken some drug (probably ergot), to produce abortion. This had produced severe pains and some hemorrhage. On examination the placenta was plainly visible at vulva; there was a very foul odor. With patient under anesthesia the placenta and then a six-months fetus were delivered manually. The position of placenta before contractions of uterus was not known.

$$
\text { C. E. MCReynotds, M.D. }
$$

\section{Submucous Resection of Deflected Nasal Septa.}

TOLEDo, Oriro, July 6, 1905.

To the Editor:-In my article on the above subject in The Journal, July 1,1905 , through an inadvertence on my part a foot note says: "Read before the American Laryngological Association at Toledo, Ohio." This was an error for which I offer my apologies. It should have stated, "Read before the middle section of the American Laryngological, Rhinological and Otological Society at Toledo, Ohio, Feb. 24, 1905." By kindly publishing this letter you will greatly oblige.

Francis W. Alter, M.D.

\section{Marriages}

Alvin B. Sryder, M.D., to Miss Elizabeth Sinclair, both of Chicago, June 26.

Philip Rovvo, M.D., to Miss Panna Julia Starotto, both of Philadelphia, June 25.

Thomas G. Harnis, M.D., to Miss Dora Bailey, both of Camder, $\mathrm{W}$. Va., June 13.

John F. Sloan, M.D., Peoria, Ill., to Miss Sarah MeDonald of Brimfield, Ill., June 24.

Harry C. Buell, M.D., to Miss Anna Augusta Faber, both of Canandaigua, N. Y., June 27.
Clarence K. Dexgler, M.D., to Miss Elna May Crotsly, both of Philadelphia, June 28.

Naxcy A. Rodges, M.D., Menominee', Mich, and Rev. Chenoyeth of Toronto, Ont., June 21.

Thomas A. Speidel, M.D., Felicity, Ohio, to Miss Helen Dimmitt of Batavia, Ohio, June 27.

Oтно Algust Fiedler, M.D., Milwaukee, to Miss Elizabeth Morris of Sheboygan, Wis., June 28.

Hans Zinsset, M.D., to Miss Ruby Kunz, both of New York City, at Lake Mohegan, June 29.

William II. Reejy, M.D., 'lowanda, Ill., to Miss Nellie Fincham of Bloomington, Ill., June 29.

James W. Squires, M.D., Churubusco, Ind., to Miss Mlargaret Snyder of New Era, Ind., June 28.

Thomas M. Aderiold, M.D., Zeigler, Ill., to Miss Mae Sinicka of Chicago, at Du Quoin, Ill., June 21.

Henry Jourineay Welles, M.D., to Miss Elizabeth $M$. Jones, both of Minneapolis, Minn., June 28.

BenJamin Hall Seaking, M.D., New York City, and Miss Helene Stuckle of Montclair, N. J., June 29.

John W. Young, M.D., Fort Wayne, Ind., to Miss Ida Rhea of Frankford, Ind., at Nattawa, Mich., June 23.

Floyd Sweetland Clarke, M.D., Le Mars, Iowa, to Miss Emma Louise Cannon of Sioux City, Iowa, June 21.

\section{Deaths}

William C. Tyree. M.D. Kansas City (Mo.) Medical College 1876 , ex-president and professor of ophthalmology and otology in the Kansas City Medical College; oculist and aurist to St. Margaret's, St. Joseph's and Scarritt Hospitals, Kansas City; member of the city council from 1902 to 1904; president of the Kansas City Academy of Medicine in 1891; died at EI Paso, Texas, June 23, from tuberculosis, after an illness of eighteen months, aged 51. The active pallbearers at the funeral were members of the faculty of Kansas City Medical College. The board of aldermen, directors of the Kansas City Medical College and Kansas City Academy of Medicine adopted resolutions deploring Dr. Tyree's death.

Pascal H. Sawyer, M.D. Cleveland Medical College, 1850, one of the oldest and most prominent physicians of Cleveland; for a long time a member of the faculty of the medical depart. ment of the University of Wooster, Cleveland, died in St. Anthony's Hospital, Cleveland, June 26, from pneumonia, aged 68.

William H. Vincent, M.D. University of Buffalo (N. Y.) Medical Department, 1\$81. for several years a member of the board of supervisors of Cattaragus County, N. Y., died at his home in Hinsdale, N. Y., June 12, after a protracted illness; aged 51.

John Allen, M.D. Medical College of Ohio, Cincinnati, 1882, referee of the Kentucky State Board of Health for Kenton County, died at his home in Covington July 1 , from spinal meningitis, after an illness of ten days, aged 48 .

Charles Steinert, M.D. Berlin (Germany) Medical College, 1859, of Pittsburg, died at the home of his daughter in Waynesburg, Pa., June 26, from pneumonia, after an illness of two days, aged $6 \overline{3}$.

Isaac L. Lynch, M.D. Kentucky School of Medicine, Louisville, 1895, died at his home, Jolly Station, Breckenridge County, Ky., June 29, from tuberculosis, after a long illness: aged 36 .

C. P. Gray, M.D. College of Physicians and Surgeons, Keokuk, Iowa, 1881, of Lowry City, Mo., died at the home of his danghter in Leesville, Mo., June 20, after an illness of two years.

George Eger, M.D. Medical College of Ohio, Cincinnati, 1894, bacteriologist to St. Francis' Hospital, Cincinnati, died at his home in that city June 30 , after a short illness, aged 34 .

Otto B. Hicklin, M.D. College' of Physicians and Surgeons: Keokuk, Iowa, 1876, died at his home in New London, Mo., June 28, after a protracted illness, aged $7 \mathrm{I}$.

William C. Weed, M.D. Buffalo, 1891, died at his home in North Coshocton, N. Y., June 27, after an illness of nine months, from nephritis, aged 59 .

I. S. Bradley, M.D. Missouri Medical College, St. Louis, 1879. died at his home in Frankford, Mo., June 27, from disease of the liver. 